\title{
リニア誘導モータの拘束試験に基づく始動特性算定法
}

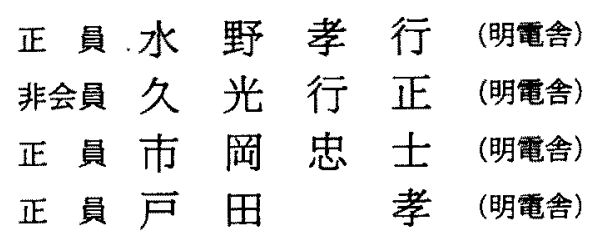

\section{A Method of Starting Performance Calculation Based on Lock Test for Linear Induction Motor}

Takayuki Mizuno, Member, Yukimasa Hisamitsu, Non-member, Tadashi Ichioka, Member, Takashi Toda, Member (Meidensha Corporation)

The equivalent circuit of the linear induction motor (LIM) is generally expressed as the same that of the rotating induction motor (IM). Then, the starting performance of the LIM is obtained using results of the no-load test and the lock test similar with the IM.

However, it is almost impossible to perform the no-load test for the LIM in the factory, because it needs a special equipment to move the mover at synchronous speed. Therefore, a new method is required to calculate the performance of the LIM by simple tests without the no-load test.

In this paper, we propose a new method which does not need the no-load test for the starting performance calculation of the LIM. At first, the results of the no-load test and the lock test for the test machine are shown. And an equivalent circuit which is suitable for the performance calculation of the LIM is proposed. Moreover, a method of determining its constants from results of the lock test is discussed.

The starting performance calculation for the LIM was made using the proposed equivalent circuit. The calculated results for the thrust vs. speed, the current vs. speed and the power input vs. slip characteristics were satisfactorily agreed with experimental results.

キーワード：リニア誘導モータ，等価回路，定数決定法，始動特性

\section{1.まえがき}

リニア誘導モー夕（以下，LIM と略記）の等価回 路は両側式(1)，片側式(2) おるび円简状 ${ }^{(3)}$ LIM 問わ ず回転形誘導モータ（以下，IM と略記）と同様に扱 うことができ，既に解析的に得られた定数により種々 の特性算定が行われている。しかし，剆定デー夕に基 づく特性算定法はほとんど検討されておらず，多くの 問題が残存しているように思われる。

LIM の等価回路が IM と同様に表される以上, IM
の規格(4)などに従って無負荷試験と拘束試験を行え ば特性が算定できることになる。しかし，直線的に移 動するLIM の場合，一般的に無負荷試験は行い難く、 実施するためには特殊な試験装置(5)が必要となる。 このため, LIM の等価回路定数を拘束試験のみのデ 一タから得ようとする検討(6) -(8) も始まっている。ま た，二次導体として平板を利用する通常のLIM て は，等価的なエアギャッブが增大して励磁りアクタン スが相刘的に小さくなり，拘束試験時に励磁りアクタ ンスの影慗が無視できなくなる。更に, 二次側の定数 
リニア誘蕉モータの始動特性算定法

が表皮好果の影讳により変化するなどLIM の特性算 定においてはその棓造および特性の特異性のため， IM の算定法とは異なった简単でかつ正確な算定法が 要望される。

そこで本論文においては，特に産業用の搬送システ ムなどに応用される小容量の低速 LIM を対象に，巻 線抵抗測定と拘束試験結果に基づくLIMの新しい始 動特性算定法(14)(15) を提案する。まず，無負荷試験お よび負荷試験が可能な LIM の実験装置を用い, 供試 機の基本特性を示す。次に，拘束試垔のデータから定 数を決定し特性を算定するのに適した等価回路の選定 を行い，定数決定法について述へる。本定数决定法は 拘束試験時に推力を測定して推力発生に有効に寄与す る二次入力と等価的な鉄損を分離し，励磁リアクタン スを合む二次側の定数を適切な関数で近似するもので ある。従って，一次㑡の鉄損をはじめ端効果に起因す る漂遊損，拘束試験時の励磁電流の影響，二次定数の 表皮効果による変化などを同時に考慮することができ る。更に, 得られた定数により始動特性を算定し, 実 湘値と比較して本特性算定法の妥当性を検討する。こ の種の低速 LIM では，端効果の影響が比較的少な く，拘束試験により運転時の定数を推定しても実用上 十分な始動特性の算定が可能となる ${ }^{(15)}$ 。

\section{2. 試作譏の概要と基本特性}

〈2・1〉試作機の概要 今回試作した試作機は片 側式三相 LIM でり，その設計仕様を表 1 に，概略 図を図 1 に示す。本試作機は無負荷試験あるいは鿓荷 試験も可能となるように，二次側鉄心をロール状にし て二次導体となるアルミ板をロール表面に張付け回転 可能としたものである。一次側固定子は軸受により振 子状に取付けられ，推力を発生すると二次側回転口一 ルの回転方向と逆方向に移動しようとする。一次側固 定子の端はロードセルにより固定され，この推力を測 定できる構成となっている。実推力はこの值をギャッ プ面に換算して得ることができる。

〈2・2〉実験装要の㩐成試験装置は図 2 に示す ように試作機を減速機付きの IM と直結し, この IM を回生機能付きのインバー夕(負荷用 INV) により 速度制御することによって任意の速度および負荷が得 られるようになっている。試作機の駆動用電源は電在 および周波数を任意に調整できるインバータ（駆動用 INV) を採用した。また, 電圧, 電流および入力は ディジタルパワーメータ (DPM) により, 推力は口 ードセルの出力をアンプ (AMP) を通して湘定する 構成となっている。
表 1 試作機の仕様

Table 1. Specifications of test machine.

\begin{tabular}{|c|c|c|c|}
\hline \multicolumn{2}{|c|}{ 定 格 } & \multicolumn{2}{|c|}{ 一次䖭線 } \\
\hline 出力-極数 & $100 \mathrm{~W}-6 \mathrm{P}$ & 䒿線擭成 & 二管巻 \\
\hline 電圧-周波数 & $200 \mathrm{~V}-10 \mathrm{~Hz}$ & 短部率 & 1 \\
\hline 同期速度 & $1.44 \mathrm{~m} / \mathrm{s}$ & 一相直列等体数 & 1,200 \\
\hline \multicolumn{2}{|c|}{ 一次鈇心(ギャップ面の寸法) } & \multirow{2}{*}{ 刑体数/スロット } & 中央部 100 \\
\hline 鉃心最 & $504 \mathrm{~mm}$ & & 両端暗 \\
\hline 鈌心程原厚 & $200 \mathrm{~mm}$ & \multicolumn{2}{|c|}{ 三次㾍体 } \\
\hline 極ピッチ & $72 \mathrm{~mm}$ & 薄体材凅 & アルミ \\
\hline 每極每相スロット数 & 2 & 禁体原 & $2 \mathrm{~mm}$ \\
\hline スロットピッチ & $12 \mathrm{~mm}$ & 碑体腷 & $380 \mathrm{~mm}$ \\
\hline スロット幅 & $8 \mathrm{~mm}$ & 竞張り鉃板厚 & $12 \mathrm{~mm}$ \\
\hline スロット深さ & $21 \mathrm{~mm}$ & 裹張り鉄板幅 & $380 \mathrm{~mm}$ \\
\hline エアギャッブ & $1.2 \mathrm{~mm}$ & ロール外径 & $764 \mathrm{~mm}$ \\
\hline
\end{tabular}

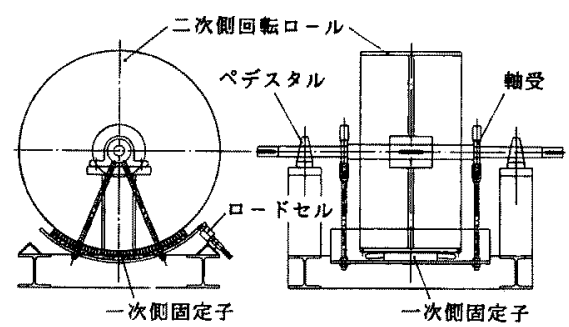

図 1 試作機の概略図

Fig. 1. Construction of test machine.

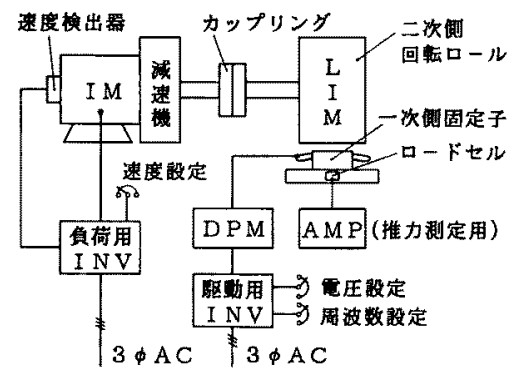

\section{図 2 実験装置の構成}

Fig. 2. Configuration of test system.

本来, 機器の基本特性の算定には電源の時間的高調 波による特性への影響を考虑して，M-Gセットなど による正弦波電源を用いるべきと考える。しかし，数 $\mathrm{Hz}$ 程度の低周波数となると発電機の電圧, 周波数精 度などに問題が生じ実用的でない。従って，ここでは インバータを用いることにしたが，高調波電流の影響 を軽隇するためIGBT (Insulated Gate Bipolar 
Transistor）を採用して搬送周波数を $10 \mathrm{kHz}$ として いる。このため電流波形は極めて正弦波に近いものを なっている。

測定に用いたディジタルパワーメータは低周波特性 を改善したものであり，2 $\mathrm{Hz}$ 程度まで安定して测定 でる周波数特性をもつ。各測定值は文献 (9)，(10) の思想に基づき，電圧についてはほぼ基本波成分を指 示する直流平均実効值表示，電流拈よび入力について は全実効值表示にて測定するものとする。なお，端効 果などの影䇾により電压, 電流に三相不平衡が存在す る場合には三相の平均をとるものとする。

〈2・3〉無負荷試騃結果図 3 に $10 \mathrm{~Hz}$ におる 試作機の無負荷試験の結果を示す。同図より明らかな ように電压と電流はほ经比関係にあり，磁気的な飽 和の影籍を受けにくいことを示している。すなわち， 小容量のLIM では，通常のIM の回路定数に比較し て励磁リアクタンスが小さく，電流を仙じめ諸特性へ の磁気的飽和の影響が少ないとみることができる。従 って，本論文の主題でるる拘束試鞅から等価回路の定 数を求特性を算定する嗄合，拘束試験が定格電圧よ り低い電圧で行われても，定格電圧での特性算定には 十分利用できることになる。

なお，定格電圧 $V_{1}$ のときの一次電流を 10 , 入力を $W_{0}$ とすると, 一次りアクタンス $X_{1}$ と等価鉄賣抵抗

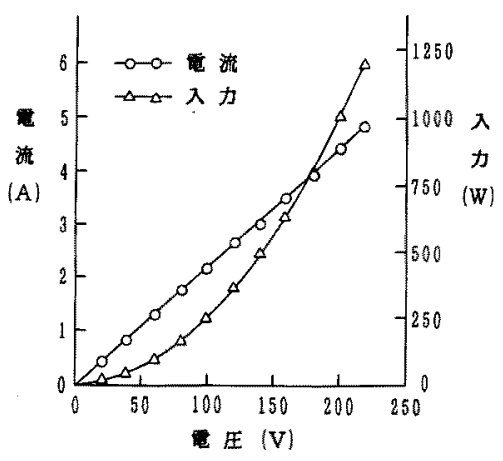

図 3 無角荷試験結果 $(10 \mathrm{~Hz})$

Fig. 3. Results of no-load test $(10 \mathrm{~Hz})$.

表 2 無負荷試験による一次定数 (一相分) Table 2. Primary constants obtained by no-load test (per phase).

\begin{tabular}{l|l}
\hline 一次巷線抵杭 & $R_{1}=14.55 \Omega$ \\
\hline 一次りアクタンス & $X_{1}=20.04 \Omega(10 \mathrm{~Hz})$ \\
\hline 鉄挸㮩挖 & $R_{m}=158 \Omega(10 \mathrm{~Hz})$ \\
\hline
\end{tabular}

$R_{m}$ は次式で部算でき，結果のみ示せば表 2 となる。

$$
\begin{aligned}
& X_{1}=\left(R_{n}^{2}+X_{n}^{2}\right) / X_{n} \\
& R_{m}=\left(R_{n}^{2}+X_{n}^{2}\right) / R_{n}
\end{aligned}
$$

$\pm こ$,

$$
\left.\begin{array}{l}
R_{n}=\frac{W_{0}}{3 I_{0}^{2}}-R_{1} \\
X_{n}=\sqrt{\left(\frac{V_{1}}{\sqrt{3} I_{0}}\right)^{2}-\left(\frac{W_{0}}{3 I_{0}^{2}}\right)^{2}}
\end{array}\right\}
$$

ただし， $X_{1}$ と $R_{m}$ 经後述の等洒回路（図6）に合せ て並列接続したときの值であり，一次抵抗 $R_{1}$ は無角 荷試験直後に測定した值である。

また，無負荷試験時の入力には機械損も含まれる が，図3より明らかなようにその值は槡めて小さいの て，ここでは機械損を無視して考文る。本論文の対象と しているLIMは小容量の低速機であり，一般的にも機 械損は十分小さく無視して差し支えないものと考える。

〈2.4〉拘束試験結果図 4 k拘束試験の結果を 示す。拘束試験は周波数 $2 \sim 11 \mathrm{~Hz}$ にわたって，浪涩 定格電流となる4A一定で行った。測定したデー夕は

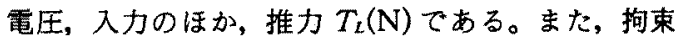
試験の結果は巻線温度に大きく影響を受けるので，各 点の測定で一定時間無負荷運転し, 巻線温度がほぽ定となる条件で測定した。この試験中における巻線抵 抗は $15.15 \pm 0.15 \Omega\left(75.3 \pm 3^{\circ} \mathrm{C}\right)$ の範国にあった。 また，二次側はロール状にしたことで熱容量と放熱効 果が大きくなり，温度上暈はほとんど弪められず，温 度は周囲温度 $\left(20^{\circ} \mathrm{C}\right)$ より $2 \sim 3^{\circ} \mathrm{C}$ 高い程度であった。 なお，一般には巻線温度を管理しての拘束試験は実用 的でなく，実使用状態での温度も拘束試駼時とは異な

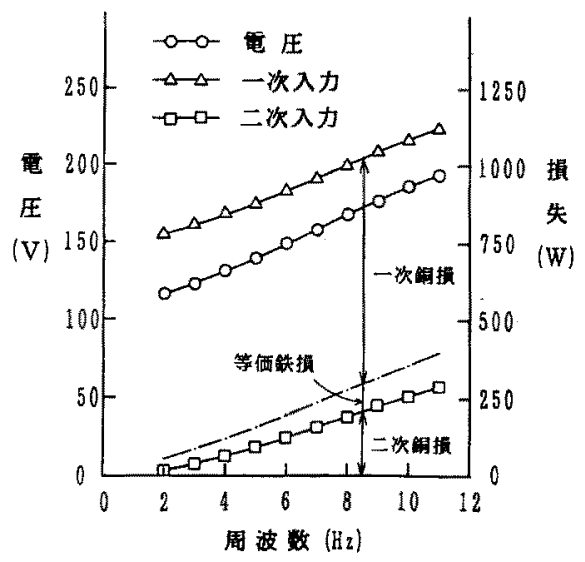

図 4 拘束試験結果 (4 A)

Fig. 4. Results of lock test (4A).

T. IEE Japan, Vol. 112-D, No. 2, ' 92 
った值となる。従って，拘束試硢時に一次巻線および 二次䇛体の温度を湖定し，後述する方法により得られ た定数のうち抵抗分については, 実使用状態で推定き れる温度に換算して用いるべきである。

一般的な拘束試験(4) では印加電圧が定格電圧に比 較して十分小さいため, 鉄損を無視して一次入力から 一次銅損を差し引いて二次銅損とみなしている。しか し，LIM の場合には等価エアギャッブが大きく拘束 試験時の電圧が定格電圧に近くなることもあり，鉄損 る無視できなくなる。また，時間的高調波あるいは端 効果などの影響により漂遊損の増大が予想される。そ こで推力発生に有効に奇与する二次入力を求めるた め, 拘束試験時に推力を測定する方法を導入する。推 力が得られると同期速度 $v_{s}(\mathrm{~m} / \mathrm{s})$ との関係加ら, 二 次入力 $P_{L 2}$ は (4) 式によって求められる。

$$
P_{L 2}=T_{L} v_{S}
$$

拘束時にはこの二次入力のすべてが二次銅損とみな せるので，この值を利用すれば，拘束試験時における 鉄損，漂遊損などを分離することができ，定数算出の 精度が向上する。図 4 には前述のデータのほか，損失 を分離するため一次入力より一次銅損を差し引いた線 も描いてある。この結果, 拘束試験時の一次入力には 一次抢よび二次銅損のほか，約 $10 \%$ の付加的な賣失 が含まれていることがわかる。この付加的損失を等価 鉄損として取扱うことにする。

以上の結果より，拘束試験に㧍けるLIM の等価鉄 損は二次銅損に対して無視できなくなり，推力に寄与 する有効二次入力と等価鉄損を緟密に分離することが 重要と考える。従って，本定数決定法では拘束試験時 に推力を測定して二次銅損を決定する方法をとること にする。小容量機を対象とした場合，拘束試験時つ推 力は比較的容易に測定でき，試験における困難さ恃伴 うものではないと考える。また，等価鉄損が無視でき る場合には推力測定を省略して, 一次銅損以外の損失 がすべて二次銅損であるとすればよい。

\section{3. 等価回路の選定と定数決定法}

〈3.1〉等価回路 IM の特性算定には一般的に T形等価回路が用いられ，その定数決定法もほほ確 立したとみることができる。しかし，無負荷試験が必 要であることはもとより，一次および二次の漏れりア クタンスの裂密な分雜が困難であり，LIMのように 表皮奻果の影響により二次定数が変化する場合には好 ましくない。また，等価エアギャップがIMに比較し て相対的に大きいLIM ては, 拘束時にも励磁電流分

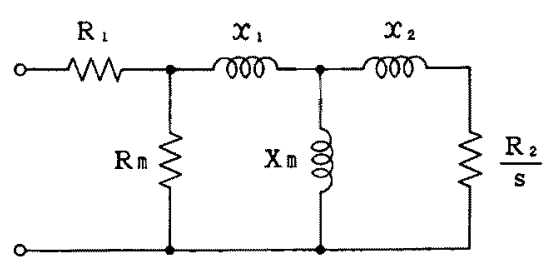

园 $5 \pi$ 形等洒回路

Fig. 5. $\pi$-type equivalent circuit.

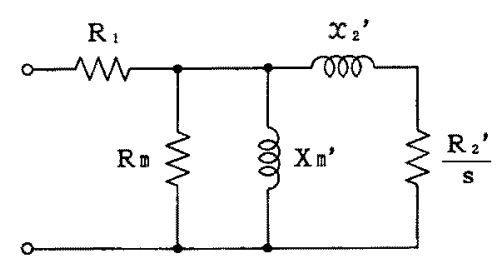

図 6 LIM 特性算定のための等価回路

Fig. 6. Equivalent circuit of LIM for performance calculation.

が相当量流れることを前提にする必要があることなど 種々の問題があるため，IMの算定法(4)をそのまま LIM に適用するにはむりがあるように思われる。従 って,ここでは LIM の特性を拘束試験のみの結果か ら算定するという目的に対して, 最も都合の良い等価 回路を考える。

前述のように，本拘束試験では推力を湘定して等価 鉄損を分離するので，等価回路上鉄損抵抗の取扱いや すい形とする必要がある。図 5 に示す等価回路は $\pi$ 形等価回路としてょく知られているが, 鉄損抵抗がー 次抵抗の直後に捜入されるため，等価鉄損からの鉄損 抵抗の算出が容易となる。ただし，図 5 において， $R_{1}$ :一次抵抗, $x_{1}$ :一次漏九リアクタンス, $X_{m}$ : 励 磁りアクタンス, $R_{2}$ : 二次抵抗, $x_{2}:$ 二次漏れリア クタンス, $R_{m}$ : 等価鉄蹎抵抗， $s:$ 滑りである。

また, IMの等価回路はその電圧方程式を適当な巻 数比 $\alpha$ を考慮してテンソル変換することにより， 種々の等価回路で表されることが知られている(11。 文献(12)では図 5 の $\pi$ 形等価回路加ら出発して図 6 の等価回路を導出している。図6は見掛け上一次漏れ リアクタンスが消去された形となっているが，等価変 換を行っているので電気的には図 5 と同一のものを表 している。ただし，図6において

$$
\left.\begin{array}{l}
X_{m}^{\prime}=\alpha X_{m}=X_{1} \\
x_{2}^{\prime}=\alpha^{2} X_{2}-\alpha X_{m} \\
R_{2}^{\prime}=\alpha^{2} R_{2}
\end{array}\right\}
$$


であり， $\alpha=X_{1} / X_{m}, X_{1}$ : 一次リアクタンス $\left(X_{1}=x_{1}\right.$ $\left.+X_{m}\right), X_{2}$ : 二次リアクタンス $\left(X_{2}=x_{2}+X_{m}\right)$ であ る。すなわち， $X_{m}^{\prime}$ は表 2 に扔ける $X_{1}$ と同一のもの である。

従って, 図6の等価回路を用いると一次抢よび二次 漏れリアクタンスの分離の必要がなく，定数の算出が 容易となり無負荷試験を行わない本算定法には適した 等価回路と考えることができる。以上の理由により， LIM の始動特性算定のための等価回路としては図 6 を採用することにする。

〈3.2〉 定数算出式 LIM 等価回路を図 6 とする と, 拘束時（滑り $s=1 ）$ の等価回路は図 7 のように 表すことができる。いま, 定格周波数 $f_{n}$ で拘束試験 を行い相電圧 $V_{L}$, 電流 $I_{L}$, 入力 $W_{L}$ および推力 $T_{L}$ を測定する。そして，拘束試験終了後ただちに一相巻 線抵抗 $R_{1}$ を測定したとすると，以下の手順に従っ て, 相電圧を基準ベクトルにとった場合の各部の定 数，電圧および電流を決定することができる。

(1) 電源側から見た全抵抗

$$
R_{L}=W_{L} /\left(3 I_{L}^{2}\right)
$$

（2）電源側から見た全リアクタンス

$$
\begin{aligned}
& X_{L}=\sqrt{\left(V_{L} / I_{L}\right)^{2}-R_{L}^{2}} \\
& (3) \quad \text { 一次電流 } \\
& \dot{I}_{L}=V_{L} /\left(R_{L}+j X_{L}\right) \cdots
\end{aligned}
$$

(4) 誘起電圧

$$
\dot{V}_{L m}=V_{L}-R_{1} \dot{I}_{L}
$$

(5) 二次入力 $P_{L 2}:(4)$ 式

(6) 等洒鉄損

$$
W_{L m}=W_{L}-3 R_{1} I_{L}^{2}-P_{L 2}
$$

(7) 等価鉄損抵抗

$$
R_{m}=3 V_{L m}^{2} / W_{L m}
$$

\section{（8）鉄損電流}

$$
\dot{I}_{R m}=\dot{V}_{L m} / R_{m}
$$

（9）等価二次電流

$$
\dot{I}_{L 2}=\dot{I}_{L}-\dot{I}_{R m}
$$

(10) 等価二次インピーダンス

$$
\dot{Z}_{2 E(S=1)}=R_{2 E(s=1)}+j X_{2 E(S=1)}
$$

ここに,

$$
R_{2 E(S=1)}=P_{L 2} /\left(3 I_{L 2}^{2}\right)
$$

$$
X_{2 E(S=1)}=\sqrt{\left(V_{L m} / I_{L 2}\right)^{2}-\left\{R_{2 E(S=1)}\right\}^{2}}
$$

ここて，等価二次電流は励磁電流と二次電流の和を 表し，等価二次インピーダンスは $X_{m}^{\prime}$ を含む二次側の 全インピーダンスを表すものとする。

一方，任意の滑りsにおける等価二次インピータン 又を図 6 の等価回路より求め, 抵抗分を $R_{2 E(S)}$, リア クタンス分を $X_{2 E(S)}$ とおくと, 両式の関係から二次 定数 $R_{2}^{\prime}$ および $x_{2}^{\prime} か ゙(17)$ 式および(18)式として求め られる。

$$
\begin{aligned}
& R_{2}^{\prime}=\frac{s R_{2 E(S)} X_{m}^{\prime 2}}{\left\{R_{2 E(S)}\right\}^{2}+\left\{X_{2 E(S)}-X_{m}^{\prime}\right\}^{2}} \\
& x_{2}^{\prime}=\frac{X_{m}^{\prime}\left[X_{2 E(S)} X_{m}^{\prime}-\left\{Z_{2 E(S)}\right\}^{2}\right]}{\left\{R_{2 E(S)}\right\}^{2}+\left\{X_{2 E(S)}-X_{m}^{\prime}\right\}^{2}}
\end{aligned}
$$

しかし，現段陼で求められる諸量は(16)式までであ り, 二次定数は $X_{m}^{\prime}$ が不明であるため決定できない。

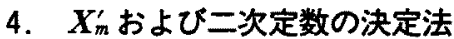

無負荷試験を行わないで $X_{m}^{\prime}$ を決定する方法とし て, 著者らが提案(日)したように，異なった周波数の 数点の拘束試験の結果から図式的に決定する方法があ る。しかし, 測定点が多くなること, 作図が必要なこ となど簡便な方法とは言い難い。また，二次定数は表 皮効果の影響を受けて滑りによって変化するので, 滑 りの関数として表すことが望ましい。ここでは， $X_{m}^{\prime}$ を含む等価二次インピーダンスの近似式を用いて, $X_{m}^{\prime}$ おょび二次側の定数を算出する方法を考える。

〈4・1〉等価二次インピータンスの近似式 一般 k, LIM の二次電流は瀜電流となり無限の自由度を もって流れる。従って,この現象を無限個の二次回路 を用いて表すことにすれば，二次側の等価回路は図 8 のように考えることができる。ただし， $r_{1}, r_{2}, r_{3}, \cdots$, $x_{1}, x_{2}, x_{3}, \cdots$ 各二次回路の抵抗, 漏れリアクタン

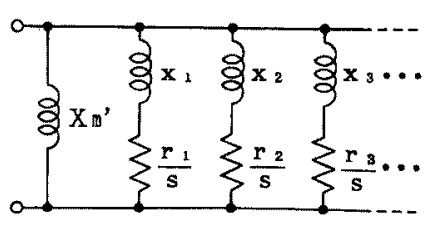

図 8 表皮効果を考慮した二次側等価回路 Fig. 8. Secondary equivalent circuit taking skin effect into consideration. 
スを表す。本特性算定のための等価回路は図 6 を採用 するが，竔密には図 6 の二次側は図 8 の合成を表して いることになる。

図 8 より合成インピーダンスを求め, 各りアククタ ンス分が周波数に比例することを考虑すれば、等価二 次インピーダンスの抵抗分およびリアクタンス分が滑 り $s$ 周波数 $f$ の関数として表され，それそれれ(19) 枋よび(20)式となる(15)。

$$
R_{2 E(s)}=f \frac{b_{1}(s f)+b_{2}(s f)^{3}+b_{3}(s f)^{5}+\cdots}{a_{1}+b_{2}(s f)^{2}+a_{3}(s f)^{4}+a_{4}(s f)^{6}+\cdots}
$$

$$
X_{2 E(S)}=f \frac{c_{1}+c_{2}(s f)^{2}+c_{3}(s f)^{4}+c_{4}(s f)^{6}+\cdots}{a_{1}+a_{2}(s f)^{2}+a_{3}(s f)^{4}+a_{4}(s f)^{6}+\cdots}
$$

ただし，係数 $a_{1}, a_{2}, \cdots, b_{1}, b_{2}, \cdots, c_{1}, c_{2}, \cdots$ は 図 80 等価回路定数で決まる定数でるが, 本特性算 定法ではこれらの係数を拘束試験（ $s=1$ の状態）に よって求めることになる。

詳細は省略するが，異なった周波数での拘束試験を 数回行い, 各周波数における等価二次インピーダンス が得られると, 有理関数近似の方法 ${ }^{(13)} に$ 従って上式 の各係数を決定することができる。この埸合の近似精 度は拘束試験のデータの数, 上式において何次の項ま で考慮するかに依存する。

しかし，実際に図4に示す2 11 Hzの10点での テータを基に，(19)式および(20)式の分子分母の第 2 項まて考慮した場合と，同様に第 5 項までを考虑した 場合とで有理関数近似法により各係数を求め， $R_{2 E}$ お よび $X_{2 E}$ を算定すると結果は両者ともほとんど同一 でった 一ダンスは (19)式および(20)式の第2 項まで考慮すれ ば十分近似できることになる。

従って，ここてい(19)式拈よひ(20)式の分子分母の 第 2 項までをとり，更に分子分母を $b_{1}$ て除して(21) 式枋よび(22)式の形で等価二次インピーダンスの抵抗 およU゚リアクタンスを表すことにする。

$$
\begin{aligned}
& R_{2 E(s)}=f \frac{s f+b_{2}^{\prime}(s f)^{3}}{a_{1}^{\prime}+a_{2}^{\prime}(s f)^{2}} \\
& X_{2 E(s)}=f \frac{c_{1}^{\prime}+c_{2}^{\prime}(s f)^{2}}{a_{1}^{\prime}+a_{2}^{\prime}(s f)^{2}}
\end{aligned}
$$

また，現実の算定法としては，前述の有理関数近似 などの数值解析を用いなくても，比較的容易に定数が 決定でき，ある程度の精度が確保されれば十分である と考える。そこで，拘束試験の回数を少なくして，測 定テータから直接保数が得られる奏用的な方法を㭘討 する。

\section{〈4-2〉等価二次インピーダンスの決定法}

式および(22)式の係数を決定するにあたり，係数は全 部で5蔨あるので一周波数の拘束試験では決定できな い。異なった任意の3 周波数ての拘束試誤の結果を用 いれば，(21)式むよび(22)式を連立させた方程式によ り各係数を決定できる。ここでは便宜上定格周波数 $f_{n}$ とその(1/2)周波数および(1/4)周波数における拘 束試験の結果より各係数を算出することにする。

各々の周波数での等価二次インピーダンスを求め, $f_{n}$ における值を

$$
\begin{gathered}
\dot{Z}_{2 E}=R_{2 E}+j X_{2 E} \\
f_{n} / 2 \text { における値を } \\
\dot{Z}_{2 E}^{\prime}=R_{2 E}^{\prime}+j X_{2 E}^{\prime} \\
f_{n} / 4 \text { におる値を } \\
\dot{Z}_{2 E}^{\prime \prime}=R_{2 E}^{\prime \prime}+j X_{2 E}^{\prime \prime}
\end{gathered}
$$

と表すことにする。たたしし， $X_{2 E}^{\prime \prime}$ は係数の算出に使用 しない。

(23) 〜 (25) 式の值と，試験特の周波数および $s=1$ を考慮して(21)式および(22)式の各係数を求めると，

$$
\left.\begin{array}{l}
a_{1}^{\prime}=A_{1} f_{n}^{2} \\
a_{2}^{\prime}=A_{2} \\
b_{2}^{\prime}=B_{2} / f_{n}^{2} \\
c_{1}^{\prime}=C_{1} f_{n} \\
c_{2}^{\prime}=C_{2} / f_{n}
\end{array}\right\}
$$

$\geq 2 k$

$$
\begin{aligned}
A_{1}= & \left(-R_{2 E}+5 R_{2 E}^{\prime}-4 R_{2 E}^{\prime \prime}\right) / D \\
A_{2}= & \left(R_{2 E}-20 R_{2 E}^{\prime}+64 R_{2 E}^{\prime \prime}\right) / D \\
B_{2}= & 16\left(5 R_{2 E} R_{2 E}^{\prime \prime}-R_{2 E} R_{2 E}^{\prime}\right. \\
& \left.-4 R_{2 E}^{\prime} R_{2 E}^{\prime \prime}\right) / D \\
C_{1}= & \left(\left(8 X_{2 E}^{\prime}-X_{2 E}\right) A_{1}+\left(2 X_{2 E}^{\prime}\right.\right. \\
& \left.\left.-X_{2 E}\right) A_{2}\right\} / 3 \\
C_{2}= & \left(4\left(X_{2 E}-2 X_{2 E}^{\prime}\right) A_{1}+2\left(2 X_{2 E}\right.\right. \\
& \left.\left.-X_{2 E}^{\prime}\right) A_{2}\right\} / 3 \\
D= & 64 R_{2 E}^{\prime} R_{2 E}^{\prime \prime}+R_{2 E} R_{2 E}^{\prime} \\
& -20 R_{2 E} R_{2 E}^{\prime \prime}
\end{aligned}
$$

以上により各係数が求まりこれを(21)式および (22)式に代入すれば任意の周波数，骬りに乱りる等価 三次インピーダンスを求めることができる。

また， $X_{m}^{\prime}$ は $X_{2 E(s)}$ のs=0のときの值であるので, (22)式より

$$
X_{m}^{\prime}=X_{2 E(S=0)}=\left(c_{1}^{\prime} / a_{1}^{\prime}\right) f
$$

として求めることができる。

なお，定格周波数運転時を考えれば， $f=f_{n}$ として 
表 3 近似式の係数算出結果

Table 3. Coefficients of approximate formulas.

\begin{tabular}{|c|c|c|c|c|}
\hline \multirow{2}{*}{\multicolumn{2}{|c|}{$\frac{\text { 算定周波数 }}{\text { 拘束坛駼周波数 }}$}} & \multicolumn{3}{|c|}{$10 \mathrm{~Hz}$} \\
\hline & & $10 \mathrm{~Hz}$ & $5 \mathrm{~Hz}$ & $2.5 \mathrm{~Hz}$ \\
\hline \multicolumn{2}{|c|}{$R_{2(\{\leq 1)}$} & 5.892 & 2.050 & 0.580 \\
\hline \multicolumn{2}{|c|}{$X_{2 E S S=1)}$} & 16.21 & 9.286 & 5.432 \\
\hline$A_{1}$ & \multicolumn{2}{|c|}{0.1028} & $C_{1}$ & 2.070 \\
\hline$A_{2}$ & \multicolumn{2}{|c|}{0.1015} & $C_{2}$ & 1.242 \\
\hline$B_{2}$ & \multicolumn{2}{|c|}{0.2035} & - & - \\
\hline$X_{m}$ & \multicolumn{2}{|c|}{$20.14 \Omega$} & $R_{n}$ & $131.1 \Omega$ \\
\hline
\end{tabular}

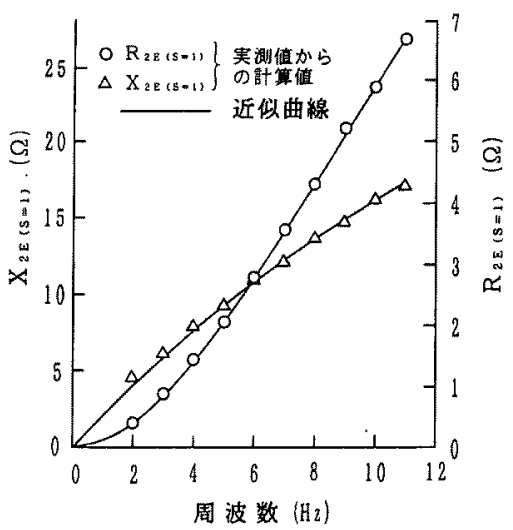

図 9 拘束時等価二次インピーダンス

Fig. 9. Equivalent secondary impedance at standstill.

$$
\begin{aligned}
& R_{2 E(s)}=\frac{s+s^{3} B_{2}}{A_{1}+s^{2} A_{2}} \\
& X_{2 E(s)}=\frac{C_{1}+s^{2} C_{2}}{A_{1}+s^{2} A_{2}} \\
& X_{m}^{\prime}=C_{1} / A_{1} \ldots \ldots \ldots .
\end{aligned}
$$

$$
\text { と表すことができる。 }
$$

〈4・3〉各定数の算出結果 表 3 には $f_{n}=10 \mathrm{~Hz}$, $f_{n} / 2=5 \mathrm{~Hz}$ および $f_{n} / 4=2.5 \mathrm{~Hz}$ の 3 周波数における 拘束試験の結果より求めた $R_{2 E(s=1),} X_{2 E(S=1)}$ の各值, および前述の係数算出方法に従って計算した各係数を 示す。また, 表 3 の係数を用いて(21)式抢よび(22)式 により算定した拘束時 $(s=1)$ における等価二次イン ピーダンスの周波数に対する近似曲線と, 各周波数に おける拘束試験の結果より(6)〜(16)式に従って求め た值（実測值からの計算値）との比較を図 9 に示す。 図 9 より, 実測值からの計算值と近似式との詔差が低 周波領域にて若干存在するものの，全般的に本近似式 により等価二次インピーダンスの抵抗分およびリアク

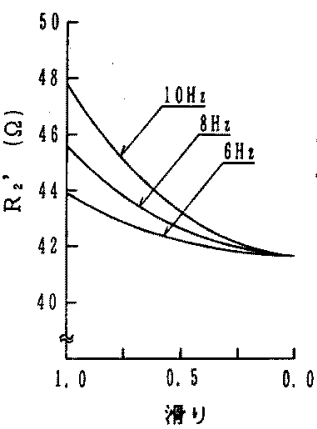

(a) $R_{2}^{\prime}$

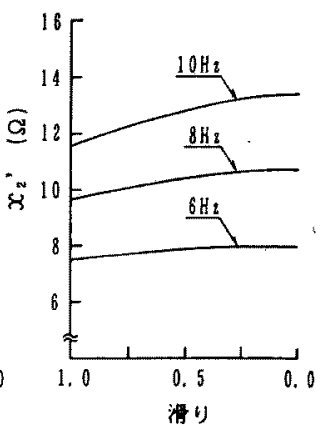

(b) $x_{2}^{\prime}$
図 10 二次定数の滑りに対する変化

Fig. 10. Frequency characteristics of secondary constants.

タンス分が良好に近似できることがわかる。

また, 表 $3 に は(31)$ 式および(11)式により計算した 定格周波数における $X_{m}^{\prime}$ および $R_{m}$ の值も示している が, 前述の無負荷試験の結果（表 2 ）と比較すると, $X_{m}^{\prime}\left(X_{1}\right.$ と等価) については良好な一致を示している といえる。 $R_{m}$ については，17\%程度小さめの值とな つた。すなわち，拘束試験と無負荷試験における等価 鉄損の差が若干現れているものと考える。しかし後述 するように，等洒鉄損の推力および電流に与える影響 は少ないので，各周波数において拘束試験の結果から 求めた $R_{m}$ を滑りに対して一定であると仮定して検討 を進める。

（21）式および(22)式により計算される任意の周波数 および滑りに対する等価二次インピーダンスと，(28) 式より得られる $X_{m}^{\prime}$ の値を(17)式扔よび(18) 式に代入 すれば，この運転状態での $R_{2}^{\prime} お よ ひ ゙ ~ x_{2}^{\prime}$ を決定する ことができる。図 10 は定格周波数 $10 \mathrm{~Hz}$ のほか，8 $\mathrm{Hz}$ および $6 \mathrm{~Hz}$ での滑りに対する $R_{2}^{\prime} お よ ひ ゙ ~ x_{2}^{\prime}$ の変 化の様子を表したものでる。これらの図から明らかな ように, LIM の二次定数は周波数抢よび滑りによっ て変化する。一般に二次定数への表皮効果の影響は滑 り周波数（sf）が高くなると抵抗分は大きく，漏れり アクタンス分は小さくなる傾向にあるが，その特徵を よく表しているといえる。

\section{5. 特性算定結果と実測值との比較}

等価回路の定数が得られれば，等価回路についての 電圧方程式より種々の特性は容易に求められるので, 詳細は省略し,ここでは速度一推力・電流特性と損失 特性の実測結果と算定結果の比較のみ示し，本算定法 の妥当性を検討する。なお，実測は図 2 の試験装置に 
より巻線温度が拘束試験時とほほ同程度となる状態て 行った。

〈5・1〉速度-推力・奄流特性図 11 および図 12 に, 速度一推力特性於よび速度一電流特性の実測值と前 章て算出した定数を用いた特性算定値との比較を示 す。而図より，各連転周波数における推力および電流 の実測値と特性算定值は良好に一致していることがわ かる。若干てはあるが，電流の諡差が同期速度付近お よび低速領域において大きくなっている。これは二次 インピーダンスの近似式の精度, 後述の損失の影響な どによるものと思われるが, 実用的には十分な精度で 算定されているものと考える。

〈5・2〉溓り一损失特性 图 $13 に 200 \mathrm{~V}-10 \mathrm{~Hz}$ に おける滑り一損失特性を示す。図 13 に扔いて実測值か らの計算值は，各滑りにおける赛負荷試験時に一次入

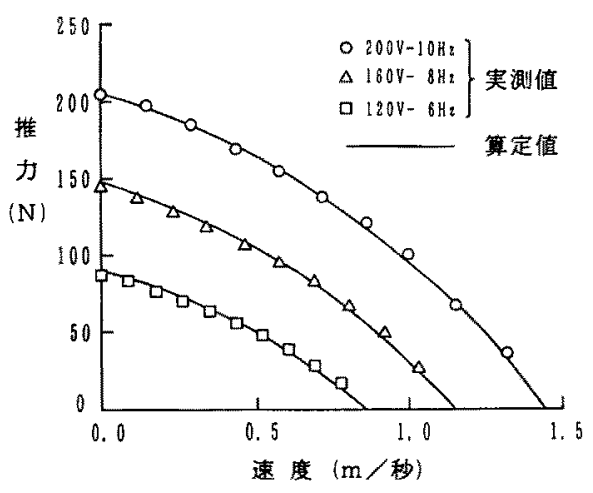

図 11 速度-推力特性

Fig. 11. Thrust vs. speed characteristics.

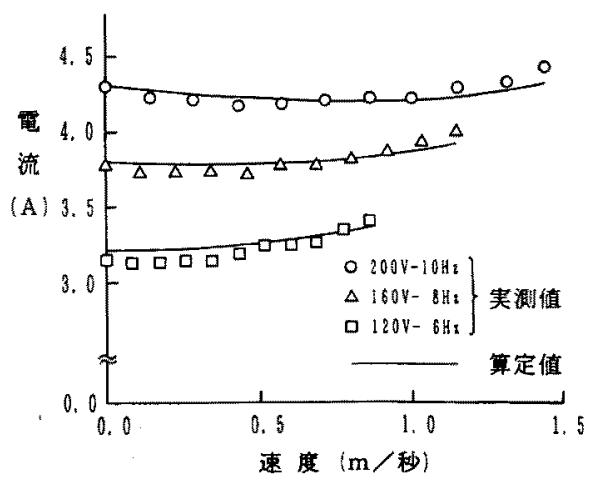

図 12 速度一電流特性

Fig. 12. Primary current vs. speed characteristics.
力と電流を測定して，一次銅損は一次電流と巻線抵 抗，二次銅損は出力と滑りの関係から，等価鉄損は一 次入力上り出力，一次銅損および二次銅損を差し引い て求めたものである。また，算定值は前章で算出した 定数を用いて等価回路より求めたものである。

図 13 において, 二次銅損は実測值からの計算值と 算定值が良好に一致するが，特に等価鉄損は同期速度 付近での誤差が大きくなっている。等価鉄損の算定値 ては，算定周波数てある $10 \mathrm{~Hz}$ の拘束試驓に上り求 めた等価鉄損抵抗を一定としているが，実際には滑り によってこの値が変化することを意味している。しか し，小容量 LIM の損失は一次銅損が支配的であり， 等価鉄損の全入力に対する割合が比較的小さいこと， 本算定法が始動特性を対象としていることなどから等 価鉄損抵抗を一定としても実用上問題はないものと考 える。

推力，二次銅損などについては，拘束試駼結果から 推力を発生する有効な二次入力を分離して，任意の滑 り周波数に対応した二次定数を算出しているので, 等 価鉄損の影響を受けにくく滑りの全範囲について良好 に一致するとみることができる。また，一次電流も等 価鉄損抵抗の影響を受けるが，等価鉄損電流は励酳電 流に比較して十分小さく無視できるので，一次電流の 誤差も少ないことになる。

従って，本算定法を用いれば，同期速度付近の損失 に若干の誤差を生じるものの, 巻線抵抗測定と拘束試 験のみにより LIM の始動特性が良好に推定できるも のと考える。

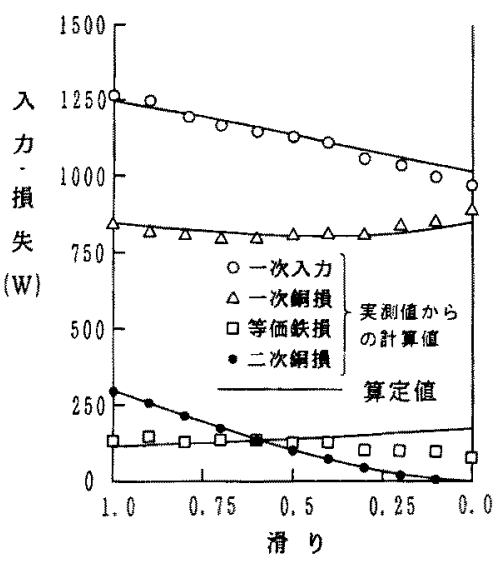

図 13 滑り一損失特性 $(200 \mathrm{~V}-10 \mathrm{~Hz})$ Fig. 13. Losses vs. slip characteristics $(200 \mathrm{~V}-10 \mathrm{~Hz})$. 


\section{6. あとがき}

以上，小容量低速 LIM の特性算定に適した等価回 路を提案し, 拘束試験と抵抗測定のみによる簡単な試 験から，等価回路定数を決定し始動特性を算定する方 法について検討した。得られた結果は電流, 推力など 実測値と算定值が良好な一致を示し，この種の LIM の始動特性算定において無負荷試験の不要な簡便なる 一方法が確立されたと考える。

得られた結果を要約すると以下のとおりである。

（1） 小容量低速 LIM では, 等価エアギャップが 大きく磁気的飽和の影響を受けにくい。また，端効果 の影響も少ないので，拘束試験によりすべての定数を 決定しても, 定格電圧における始動特性の算定に十分 利用できる。

（2）拘束試験に含まれる損失には鉄損および漂遊 損で構成される等価鉄損が多く含まれ，これを無視し た場合には正確な特性算定が不可能となる。この損失 は拘束試験時に始動推力を測定して, 等価鉄損抵抗と して考慮することができる。

（3）LIM の等価回路としては一次漏れリアクタ ンスを消去した等価回路を用いると便利である。

(4) 定数決定は, 定格周波数 $f_{n},\left(f_{n} / 2\right)$ および $\left(f_{n} / 4\right)$ の周波数における拘束試験の結果より $X_{m}^{\prime}$ を含 む二次側インピーダンスを求め,このインピーダンス を適切な関数で近似することにより，任意の周波数お

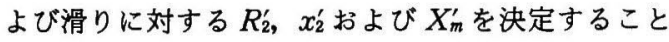
ができる。

（5）試作機による特性算定結果では算定値と実測 值が良好に一致し，十分 LIM の始動特性を検討でき るものと考える。

なお，滑りに対する等価鉄損の変化，運転特性など に対する検討は今後の課題である。

終りに, 本研究に対して種々の御協力を賜った当社 名古屋工場の関係者各位に感謝の意を表す次第であ る。

(平成 3 年 6 月 27 日受付)

$$
\text { 文献 }
$$

（1）野中・吉田：「両側式リニアモータの等価回路定数と特性計 算式」, 電学誌, 90, 890 (昭 45-5)

（2）野中・蛹口:「片側式リニアインタクションモータの近似特 性計算式について」, 電学論 B, 102, 565 (昭 57-9)

（3）内海：「円筒形リニア誘導モータの寸法倍率特性」, 同上 D, 108, 261 (昭 63-3)

(4) 電気学会軋気規格調查会: JEC-37 誘烈機 (昭 54)

(5) 電気学会磁気アクチュエー夕調查尃門委員会編: リニアモー 夕とその応用, p. 163 (昭 59-3)

（6）㥎名・大竹, 他：「片側式 LIM の T 形等価回路における特性 算定 (1) J, 平 3 電気学会全大, No. 811
（7）大竹・閔本，他：「片側式 LIM の T 形等価回路における特性 算定 $(2)$ J, 平 3 同上, No. 812

（8）水野・市岡・戸田：「拘束試䀧によるLIM の励磁リアクタン 決定法了, 平 3 同上, No. 813

（9）日本電機工業会：インバータドライフの適用針指（汎用イン バー夕), No. 148 (昭 61-6)

（10）坪井・山本・日々野：「疑似正弦波法による正弦波 PWM 1 ンバー夕駆動誘導䉓動機の運転特性の算定」, 電学論 D, 107, 1231 (昭 62-10)

（11）山村：交流モー夕の解析と制御（昭 62）オーム社

（12）石崎・平山：「誘琶機の特性算定のための定数決定法」，電学 誌, 87, 173 (昭 42-9)

（13）宇野：計算機のための数値計算（昭 38）朝會書店

（14）水野・市岡・戸田：「リニア誘型モータの始野特性算定の一 方法」, 平 3 電気学会産業沁用部門全大, No. 256

（15）水野・伊達・戸田：「低速 LIM の拘束試駼に基つくく始動特性 算定法の検钨」, 電気学会回転機研䆓, RM-91-53（平 3)

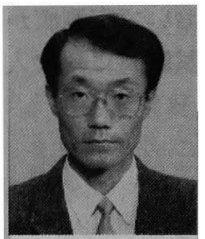

\section{水 野 孝 行 (正員)}

昭和 56 年 3 月中部工業大学大学院工 学研究科電気工学専攻博士前期課程修 了。同年 4 月(株)明電舎入社。現在, 同 社名古屋工場に勤務。この間, 主とし て, 誘導電動機の設計, 研究・開発に従事。 56 年, 平成 2 年電気学会論文賞受賞。

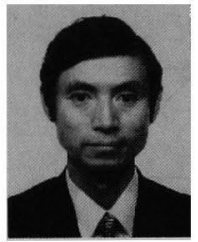

\section{久 光 行 正 (非会員)}

昭和 46 年 3 月東京電機大学機械工学 科卒業。同年 4 月(株)明電舎入社。現 在, 同社名古屋工場に勤務。この間, 主 として誘導電動機の設計, 研究・開発に 従事。機械学会会員。

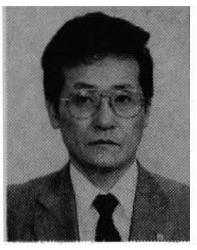

$$
\text { 市岡 忠 } \pm \text { (正員) }
$$

昭和 45 年 3 月東京工業大学電子物理 工学科卒業。同年 4 月 (株)明電舎入社。 現在, 同社名古屋工場に勤務。この間, 主として, 電動機可変速制御の研究・開 発に従事。平成 2 年電気学会論文賞受賞。

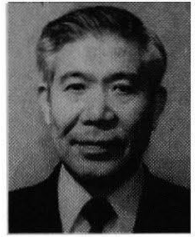

$$
\text { 戸田孝(正員) }
$$

昭和 32 年 3 月愛媛大学工学部電気工 学科卒業。同年 4 月 (株)明電舎入社。誘 導機の設計, 回転電機およびその制御の 研究業務に従事。現在, 同社技術総本部 技師長。この間, 東京電機大学 II 部, 群馬高専, 岐阜大工 学部などの非常勤講師。IEEE 会員。 